\title{
Growth Inhibition of Xanthomonas oryzae by Combination of IAA and Culture Filtrate of Rice Callus Tissues
}

\author{
Teiichi Fukam* \\ 深見悌一* : インドール酢酸とイネ・カルス組織の培養沪液との組合わせによる \\ イネ白葉枯病菌の生育阻害
}

\begin{abstract}
Rice callus tissues were induced from four rice cultivar's sprouts (Kinmaze, Kogyoku, Te-tep, and Waseaikoku No. 3). It was observed that these calli secreted high molecular weight antibiotic components against Xanthomomas oryzae into the medium during their growth, when the bacterial growth was tested on the agar medium supplemented with indole-3-acetic acid (IAA). The influences of addition of plant hormones to Murashige-Skoog's medium on growth of the rice calli and on secretion of the antibiotic component from the callus tissues were examined after incubation for 3 weeks at $27 \mathrm{C}$. Callus tissues of Kinmaze and Kogyoku secreted relatively small amounts of the antibiotic component when they grew on the medium with added low concentration $(0.05 \mathrm{ppm}$ or less) of plant hormones (IAA, 2,4-D, NAA or kinetin). However, the antibiotic activity in the culture media of Kinmaze and Kogyoku callus tissues increased almost as much as that found in the media of Te-tep and Waseaikoku No. 3 callus tissues, when they grew on the media supplemeted with higher concentration ( 0.5 to $20 \mathrm{ppm})$ of $2,4-\mathrm{D}$. On the other hand, the degree of secretion of the active component from Te-tep or Waseaikoku No. 3 callus tissues was relatively high even when they grew on the medium contained low concentration ( $0.05 \mathrm{ppm}$ or less) of plant hormones, and was mostly 10 to 100 times as much as that from Kinmaze or Kogyoku when they grew on the medium with added higher concentration of IAA, NAA or kinetin. The antibiotic component seemed to be one of IAA oxidizing enzymes, because it was a high molecular weight substance of around 32,000 daltons, it required $\mathrm{Mn}^{++}$as a cofactor, and the activity was stimulated by addition of monohydric phenol.
\end{abstract}

(Received December 28,1978)

\section{Introduction}

It is known that bacterial leaf blight disease of rice is caused by a bacterium, Xanthomonas oryzae, which invades into the vessels of leaves of rice plant and multiplies in them. However, little is known as to host-parasite relationship of this bacterium and rice plant, especially in respect to self-defense mechanism of host plant against the pathogen. ${ }^{6,4,8)}$

Horino et al.5) reported by electron-microscopic study that polysaccharide-like substances were found around the surface of invaded $X$. oryzae cells in vessels of rice leaves. They assumed that these substances might play a defensive role by enveloping the bacterial cells and by inhibiting their multiplication. It was thought

* National Institute of Agricultural Sciences, Tokyo, Japan 農業技術研究所 
to be reasonable that by using callus tissues of rice plant, the investigation of secretion of antibacterial substances from callus cells would give information about the exo-cellular defense mechanism of rice plant.

On the other hand, not a few pathogenic microorganisms are known to accumulate indole-3-acetic acid (IAA) and its related substances in host plants, or in other cases they secrete some unkown factors which stimulate their host plants to produce these indole compounds when they infect to their host plants. ${ }^{10)}$ IAA, one of the plant hormones, is thought to play many important roles in the metabolic control of host plants which are in the process of suffering the diseases or recovering from them.

In the course of search for antibacterial substances secreted from rice callus, remarkable antibacterial activity was detected from culture filtrate of callus tissues when the assay medium containing IAA was used. In the present report, research has been done on the secretion of the IAA-related antibacterial component from four kinds of the rice callus tissues cultured in the medium supplemented with several plant hormones.

\section{Materials and Methods}

Callus tissues. As the starting material for callus induction four cultivar's of seeds of rice (Kinmaze, Kogyoku, Te-tep, and Waseaikoku No. 3) were used. Each seed was removed from its husk and was sterilized by $0.5 \%$ Na-hypochlorite solution for $15 \mathrm{~min}$. After being washed with sterilized water, it was transferred to the Murashige-Skoog's medium ${ }^{7)}$ supplemented with $0.15 \%$ of casamino acid (products of Difco, vitamine-free) and $2 \mathrm{ppm}$ of 2,4-D instead of kinetin and IAA. Incubation was done for more than 3 weeks at $27 \mathrm{C}$. Callus tissues were generated mostly around the basic parts of the sprouted shoot and root. The induced callus tissues were then transferred to the same medium at 3 weeks intervals successively.

In the studies of growth of the calli and of secretion of the antibiotic component from them, Murashige-Skoog's medium without plant hormones containing $0.15 \%$ casamino acid was used as the basal medium, to which graduated concentrations of each auxin and/or kinetin were added. Each rice callus was incubated on the agar slant medium ( $12 \mathrm{ml}$ each in volume) for 3 weeks at $27 \mathrm{C}$. The grown callus pieces were separated and collected from the agar medium and their fresh weights were measured. Culture liquid was then extracted from the remaining agar medium after freezing and thawing, followed by filtration. It was diluted, filtered through Millipore filter and its antibiotic activity against $X$. oryzae was assayed.

Test microorganism. Xanthomonas oryzae $\mathrm{Q} 6808$ was used as a test microorganism. The bacterium was maintained on modified Watanabe's medium ${ }^{11)}$.

Detection and assay of the antibacterial activity For detection and assay of the antibacterial activity in the filtrate of cultures of rice callus tissues, an agar difusion method using stainless cup ( $8 \mathrm{~mm}$ in diameter) on agar plate was applied. Composition of the agar medium for the assay was as follows: Na-glutamate $1 \mathrm{~g} / \mathrm{l}$, $\mathrm{KH}_{2} \mathrm{PO}_{4} 1 \mathrm{~g} / 1, \mathrm{MgCl}_{2} \cdot 6 \mathrm{H}_{2} \mathrm{O} 0.5 \mathrm{~g} / 1, \mathrm{FeSO}_{4} \cdot 7 \mathrm{H}_{2} \mathrm{O} 0.05 \mathrm{~g} / 1, \mathrm{MnSO}_{4} \cdot 4 \mathrm{H}_{2} \mathrm{O} 0.022 \mathrm{~g} / 1$, IAA $0.025 \mathrm{~g} / 1$, sucrose $10 \mathrm{~g} / 1$, yeast extracts $1 \mathrm{~g} / \mathrm{l}$, peptone $2.5 \mathrm{~g} / 1$ and agar $10 \mathrm{~g} / \mathrm{l}, \mathrm{pH}$ 6.5. Samples to be tested were diluted with $0.01 \mathrm{M}$ phosphate buffer ( $\mathrm{pH} 6.0$ ) contained $0.2 \mathrm{M} \mathrm{NaCl}$ when it is necessary and filtered through Millipore filter HAWP $(0.45 \mu \mathrm{m}$ in pore size $)$ to avoid a microbial contamination. These were then applied into the cups placed on the agar plate of the medium containing suspended cells of $X$. oryzae. After incubation for 3 days at $27 \mathrm{C}$, the inhibition zones formed around the cups were examined and the diameters were measured. 
The antibiotic activity of IAA itself against $X$. oryzae was examined by the same assay method. The result indicated that addition of $175 \mathrm{ppm}$ of IAA to the medium was inhibitory for growth of $X$. oryzae, but that of $125 \mathrm{ppm}$ did not inhibit the growth.

Culture filtrate of the callus tissues was also tested for the antibiotic activity by the use of the same assay medium without IAA, but none of culture filtrates of the four calli formed inhibition zones on the agar plate medium. However, a mixture of equal volume of the culture filtrate and IAA solution (10 to $150 \mathrm{ppm}$ of IAA in the mixture) showed inhibition zones around cups on the agar plate medium without IAA, almost the same result as the culture filtrate alone was poured into cups on the assay medium containing IAA.

\section{Results}

\section{Effects of addition of plant hormones to the callus medium}

At first the influence of addition of plant hormones to the culture medium of rice callus on secretion of the antibiotic components from the callus tissues and the influence of it on their growth were studied, because plant hormones are the most influential factors to the callus cells among various constiuents containing in a tissue culture medium.

Effects of addition of IAA to the medium on the growth of the calli and the degree of secretion of the antibiotic component were shown in Table 1 . As for the callus growth, no distinct stimulation was observed in these four kinds of rice

Table 1. Antibacterial activity of culture filtrates of the rice calli incubated on the media supplemented with IAA

\begin{tabular}{|c|c|c|c|c|c|c|c|c|c|c|c|c|}
\hline \multirow{3}{*}{$\begin{array}{c}\text { Conc. } \\
\text { of } \\
\text { IAA }\end{array}$} & \multicolumn{12}{|c|}{ Culture filtrate } \\
\hline & \multicolumn{3}{|c|}{ Kinmaze } & \multicolumn{3}{|c|}{ Kogyoku } & \multicolumn{3}{|c|}{ Te-tep } & \multicolumn{3}{|c|}{ Waseaikoku No. 3} \\
\hline & $10^{-1}$ & $10^{-2}$ & $10^{-3 *}$ & $10^{-1}$ & $10^{-2}$ & $10^{-3}$ & $10^{-1}$ & $10^{-2}$ & $10^{-3}$ & $10^{-1}$ & $10^{-2}$ & $10^{-3}$ \\
\hline $0 \mathrm{ppm}$ & + & $\frac{-}{1.34^{\mathrm{b})}}$ & -a) & - & $\begin{array}{c}- \\
0.89\end{array}$ & - & $H$ & $\begin{array}{c}+ \\
0.78\end{array}$ & - & $H$ & $\begin{array}{c}+ \\
0.93\end{array}$ & - \\
\hline 0.05 & H & $\begin{array}{c}- \\
1.60\end{array}$ & - & - & $\begin{array}{c}- \\
1.07\end{array}$ & - & H & $\begin{array}{c}+ \\
0.82\end{array}$ & - & $H$ & $\begin{array}{c}\text { H } \\
0,94\end{array}$ & - \\
\hline 0.5 & H & $\begin{array}{c}+ \\
1.36\end{array}$ & - & - & $\begin{array}{c}- \\
1.10\end{array}$ & - & H & $\begin{array}{c}\text { H } \\
0.90\end{array}$ & - & $H$ & $\begin{array}{c}\text { \# } \\
1.01\end{array}$ & + \\
\hline 2 & H & $\begin{array}{c}+ \\
1.59\end{array}$ & - & - & $\begin{array}{c}- \\
1.08\end{array}$ & - & H & $\begin{array}{c}\text { H } \\
0.80\end{array}$ & - & $H$ & $\begin{array}{c}H \\
0.84\end{array}$ & - \\
\hline 10 & H & $\begin{array}{c}- \\
1.66\end{array}$ & - & - & $\begin{array}{c}- \\
0.92\end{array}$ & - & $H$ & $\begin{array}{c}- \\
0.62\end{array}$ & - & $H$ & $\begin{array}{c}+ \\
0.65\end{array}$ & - \\
\hline 20 & $H$ & $\begin{array}{c}- \\
1.50\end{array}$ & - & - & $\begin{array}{c}- \\
0.69\end{array}$ & - & $H$ & $\begin{array}{c}- \\
0.57\end{array}$ & - & H & $\begin{array}{c}+ \\
0.76\end{array}$ & - \\
\hline
\end{tabular}

* Degree of dilution of culture filtrate

a) $\mathrm{H},+$, and - indicate sizes of diameter of inhibition zones formed on the medium plate. + , $>20 \mathrm{~mm} ;+, 10 \sim 20 \mathrm{~mm} ;-,<10 \mathrm{~mm}$.

b) Growth of calli expressed by their fresh weights ( $\mathrm{gr}$.) after incubation for 3 weeks at $27 \mathrm{C}$. 
calli by addition of 0 to $20 \mathrm{ppm}$ of IAA to the medium. On the other hand, secretion of the antibiotic activity was different by each callus in each medium of the calli. Te-tep and Waseaikoku No. 3 callus tissues secreted only small amounts of it when they grew on the media containing low concentration $(0.05 \mathrm{ppm}$ or less) of IAA. Addition of higher concentration $(0.5$ to $20 \mathrm{ppm})$ of IAA to the callus medium slightly stimulated secretion of the active component by the callus tissues except for Kogyoku callus. Optimal concentration of IAA for the secretion seemed to be 0.5 to $2 \mathrm{ppm}$ in the three kinds of calli.

When Kinmaze or especially Kogyoku callus tissues were incubated on the medium supplemented with $2,4-\mathrm{D}$, the activity in those culture filtrates increased remarkably as compared with those cases with IAA addition. The secretion of the active component from Te-tep and Waseaikoku No. 3 calli also increased to some extent by 2,4-D addition. (Table 2)

Table 2. Antibacterial activity of culture filtrates of the rice calli incubated on the media supplemented with $2,4-\mathrm{D}$

\begin{tabular}{|c|c|c|c|c|c|c|c|c|c|c|c|c|}
\hline \multirow{3}{*}{$\begin{array}{c}\text { Conc. } \\
\text { of } \\
2,4-D\end{array}$} & \multicolumn{12}{|c|}{ Culture filtrate } \\
\hline & \multicolumn{3}{|c|}{ Kinmaze } & \multicolumn{3}{|c|}{ Kogyoku } & \multicolumn{3}{|c|}{ Te-tep } & \multicolumn{3}{|c|}{ Waseaikoku No. 3} \\
\hline & $10^{-1}$ & $10^{-2}$ & $10^{-3 *}$ & $10^{-1}$ & $10^{-2}$ & $10^{-3}$ & $10^{-1}$ & $10^{-2}$ & $10^{-3}$ & $10^{-1}$ & $10^{-2}$ & $10^{-3}$ \\
\hline $0 \mathrm{ppm}$ & - & $\begin{array}{l}- \\
\left..58^{b}\right)\end{array}$ & -a) & + & $\begin{array}{c}- \\
0.67\end{array}$ & - & $H$ & $\begin{array}{c}\text { H } \\
0.86\end{array}$ & - & $H$ & $\begin{array}{c}\text { H } \\
0.99\end{array}$ & - \\
\hline 0.05 & $H$ & $\begin{array}{c}- \\
1.60\end{array}$ & - & H & $\begin{array}{c}- \\
0.73\end{array}$ & - & H & $\begin{array}{c}\text { H } \\
0.99\end{array}$ & + & H & $\begin{array}{c}\text { H } \\
0.92\end{array}$ & + \\
\hline 0.5 & H & $\begin{array}{c}\text { H } \\
1.62\end{array}$ & + & H & $\begin{array}{c}\# \\
0.76\end{array}$ & - & $H$ & $\begin{array}{c}\text { H } \\
0.85\end{array}$ & - & $H$ & $\begin{array}{c}\text { H } \\
0.88\end{array}$ & - \\
\hline 2 & H & $\begin{array}{c}\text { H } \\
1.28\end{array}$ & + & $H$ & $\begin{array}{c}H \\
0.87\end{array}$ & - & H & $\begin{array}{c}\text { H } \\
0.95\end{array}$ & + & $H$ & $\begin{array}{c}\text { H } \\
0.88\end{array}$ & - \\
\hline 10 & $H$ & $\begin{array}{c}H \\
1.25\end{array}$ & + & $H$ & $\begin{array}{c}\text { \# } \\
0.87\end{array}$ & + & H & $\begin{array}{c}+ \\
0.96\end{array}$ & + & $H$ & $\begin{array}{c}\text { H } \\
0.69\end{array}$ & - \\
\hline 20 & $H$ & $\begin{array}{c}\text { H } \\
1.03\end{array}$ & + & $H$ & $\begin{array}{c}\text { H } \\
0.86\end{array}$ & + & $H$ & $\begin{array}{c}\text { H } \\
0.86\end{array}$ & + & $H$ & $\begin{array}{c}H \\
0.67\end{array}$ & - \\
\hline
\end{tabular}

*, a), and b) indicate the same as Table 1 .

The effects by addition of $\alpha$-naphthaleneacetic acid (NAA) to the culture medium on the callus growth and on the secretion of the active component were also examined. (Table 3) It was observed that secretion of the active component from Kinmaze and Kogyoku calli scarcely occurred, and those from Te-tep and Waseaikoku No. 3 calli were almost the same degree irrespective of the concentration of 0 to $20 \mathrm{ppm}$ of NAA.

Next, the influence by addition of kinetin to the callus medium was studied at the range of concentration from 0 to $10 \mathrm{ppm}$. (Table 4) Secretion of the active component from each callus increased slightly by kinetin addition. Especially Waseaikoku No. $3 \mathrm{kept}$ relatively high level through the concentration range.

In plant tissue culture, both cytokinin and auxin are often used as the constituents in the media to get good growth of callus. In this experiment, the media supplemented with combinations of kinetin 0.5 ppm-IAA 2 ppm or of kinetin 2 ppm-IAA 2 ppm were tested for growth of the calli and for their secretion of the active compo- 
Table 3. Antibacterial activity of culture filtrates of the rice calli incubated on the media supplemented with NAA

\begin{tabular}{|c|c|c|c|c|c|c|c|c|c|c|c|c|}
\hline \multirow{3}{*}{$\begin{array}{c}\text { Conc. } \\
\text { of } \\
\text { NAA }\end{array}$} & \multicolumn{12}{|c|}{ Culture filtrate } \\
\hline & \multicolumn{3}{|c|}{ Kinmaze } & \multicolumn{3}{|c|}{ Kogyoku } & \multicolumn{3}{|c|}{ Te-tep } & \multicolumn{3}{|c|}{ Waseaikoku No. 3} \\
\hline & $10^{-1}$ & $10^{-2}$ & $10^{-3 *}$ & $10^{-1}$ & $10^{-2}$ & $10^{-3}$ & $10^{-1}$ & $10^{-2}$ & $10^{-3}$ & $10^{-1}$ & $10^{-2}$ & $10^{-3}$ \\
\hline $0 \mathrm{ppm}$ & + & $\begin{array}{c}- \\
\left..22^{b}\right)\end{array}$ & - a) & + & $\begin{array}{c}- \\
0.77\end{array}$ & - & $H$ & $\begin{array}{c}H \\
0.66\end{array}$ & - & $H$ & $\begin{array}{c}H \\
0.64\end{array}$ & - \\
\hline 0.05 & - & $\begin{array}{c}- \\
0.59\end{array}$ & - & - & $\begin{array}{c}- \\
1.00\end{array}$ & - & H & $\begin{array}{c}+ \\
0.58\end{array}$ & - & $H$ & $\begin{array}{c}\text { H } \\
0.73\end{array}$ & - \\
\hline 0.5 & - & $\begin{array}{c}- \\
0.72\end{array}$ & - & - & $\begin{array}{c}- \\
1.00\end{array}$ & - & H & $\begin{array}{c}\text { H } \\
0.70\end{array}$ & - & $H$ & $\begin{array}{c}\text { \# } \\
0.49\end{array}$ & - \\
\hline 2 & - & $\begin{array}{c}- \\
0.96\end{array}$ & - & - & $\begin{array}{c}- \\
0.74\end{array}$ & - & $H$ & $\begin{array}{c}H \\
0.61\end{array}$ & - & $H$ & $\begin{array}{c}\text { H } \\
0.74\end{array}$ & - \\
\hline 10 & - & $\begin{array}{c}- \\
1.51\end{array}$ & - & - & $\begin{array}{c}- \\
0.79\end{array}$ & - & $H$ & $\begin{array}{c}\text { H } \\
0.58\end{array}$ & - & $H$ & $\begin{array}{c}+ \\
0.60\end{array}$ & - \\
\hline 20 & + & $\begin{array}{c}- \\
1.85\end{array}$ & - & + & $\begin{array}{c}- \\
0.97\end{array}$ & - & H & $\begin{array}{c}\# \\
0.61\end{array}$ & - & $H$ & $\begin{array}{c}+ \\
0.78\end{array}$ & - \\
\hline
\end{tabular}

*, a), and b) indicate the same as Table 1 .

Table 4. Antibacterial activity of culture filtrates of the rice calli incubated on the media supplemented with kinetin

\begin{tabular}{|c|c|c|c|c|c|c|c|c|c|c|c|c|}
\hline \multirow{3}{*}{$\begin{array}{l}\text { Conc. } \\
\text { of } \\
\text { kinetin }\end{array}$} & \multicolumn{12}{|c|}{ Culture filtrate } \\
\hline & \multicolumn{3}{|c|}{ Kinmaze } & \multicolumn{3}{|c|}{ Kogyoku } & \multicolumn{3}{|c|}{ Te-tep } & \multicolumn{3}{|c|}{ Waseaikoku No. } \\
\hline & $10^{-1}$ & $10^{-2}$ & $10^{-3 *}$ & $10^{-1}$ & $10^{-2}$ & $10^{-3}$ & $10^{-1}$ & $10^{-2}$ & $10^{-3}$ & $10^{-1}$ & $10^{-2}$ & $10^{-3}$ \\
\hline $0 \mathrm{ppm}$ & - & $\frac{-}{\left.1.03^{b}\right)}$ & -a) $^{\text {a) }}$ & - & $\frac{-}{0.63}$ & - & H & $\begin{array}{c}- \\
0.54\end{array}$ & - & $H$ & $\begin{array}{c}+ \\
0.66\end{array}$ & - \\
\hline 0.04 & - & $\begin{array}{c}- \\
0.99\end{array}$ & - & - & $\begin{array}{c}- \\
0.96\end{array}$ & - & H & $\begin{array}{c}- \\
0.56\end{array}$ & - & H & $\begin{array}{c}\text { H } \\
0.75\end{array}$ & - \\
\hline 0.4 & H & $\begin{array}{c}- \\
1.09\end{array}$ & - & - & $\begin{array}{c}- \\
0.84\end{array}$ & - & H & $\begin{array}{c}+ \\
0.63\end{array}$ & - & $H$ & $\begin{array}{c}+ \\
0.68\end{array}$ & - \\
\hline 2 & + & $\begin{array}{c}- \\
0.47\end{array}$ & - & - & $\begin{array}{c}- \\
0.94\end{array}$ & - & H & $\begin{array}{c}- \\
0.50\end{array}$ & - & $H$ & $\begin{array}{c}+ \\
0.71\end{array}$ & - \\
\hline 10 & - & $\begin{array}{c}- \\
0.83\end{array}$ & - & $H$ & $\begin{array}{c}- \\
0.62\end{array}$ & - & $H$ & $\begin{array}{c}- \\
0.36\end{array}$ & - & H & $\begin{array}{c}+ \\
0.57\end{array}$ & - \\
\hline
\end{tabular}

*, a), and b) indicate the same as Table 1 .

nents. However, increase of either growth or secretion of the active component was not remarkable in the four kinds of calli (Table 5).

Fractionation of the active component

In order to examine characteristic properties of the antibiotic component, gel filtration of the culture liquid of the rice callus was tried by the use of Sephadex 
Table 5. Antibacterial activity of culture filtrates of the rice calli incubated on the media supplemented with kinetin and IAA

\begin{tabular}{|c|c|c|c|c|c|c|c|c|c|c|c|c|}
\hline & \multicolumn{12}{|c|}{ Culture filtrate } \\
\hline & \multicolumn{3}{|c|}{ Kinmaze } & \multicolumn{3}{|c|}{ Kogyoku } & \multicolumn{3}{|c|}{ Te-tep } & \multicolumn{3}{|c|}{ Waseaikoku No. 3} \\
\hline & $10^{-1}$ & $10^{-2}$ & $10^{-3 *}$ & $10^{-1}$ & $10^{-2}$ & $10^{-3}$ & $10^{-1}$ & $10^{-2}$ & $10^{-3}$ & $10^{-1}$ & $10^{-2}$ & $10^{-3}$ \\
\hline $\begin{array}{l}\text { Kinetin } \\
\quad 0.5 \mathrm{ppm}\end{array}$ & + & - & - a) & - & - & - & $H$ & - & - & tt & H & - \\
\hline IAA $\quad 2 \mathrm{ppm}$ & & $1.39^{b)}$ & & & 0.81 & & & 0.62 & & & 0.79 & \\
\hline $\begin{array}{ll}\text { Kinetin } & 2 \mathrm{ppm} \\
\text { IAA } & 2 \mathrm{ppm}\end{array}$ & + & $\begin{array}{c}- \\
1.22\end{array}$ & - & - & $\begin{array}{c}- \\
0.89\end{array}$ & - & H & $\begin{array}{c}- \\
0.50\end{array}$ & - & $H$ & $\begin{array}{c}+ \\
0.65\end{array}$ & - \\
\hline
\end{tabular}

*, a), and b) indicate the same as Table 1 .

column.

After Te-tep callus was incubated in Murashige-Skoog's medium (supplemented with $0.15 \%$ casamino acid and $2 \mathrm{ppm}$ of 2,4-D instead of IAA and kinetin) by shaking culture for 2 weeks at $27 \mathrm{C}$, the culture medium was collected and $20 \mathrm{ml}$ of it was concentrated to $1.5 \mathrm{ml}$ by lyophilization. The concentrate was then applied onto a Sephadex G-100 column (bed dimension; $1.77 \mathrm{~cm}^{2} \times 28 \mathrm{~cm}$ ) and was eluted with $0.05 \mathrm{M}$ phosphate buffer $(\mathrm{pH} \mathrm{6.0)}$. The effluent was fractionated to $1.5 \mathrm{ml}$ portions and the antibacterial activity and absorbance at $280 \mathrm{~nm}$ of each fraction were measured (Fig. 1).

The molecular weight of the main peak of the antibacterial activity was estimated as about 32,000 by examination of the eluted positions of authentic albumin (serum) and cytochrome $\mathrm{C}$.

Next, mixture of IAA, $\mathrm{Mn}^{++}$, and culture filtrate of kogyoku callus (grown on

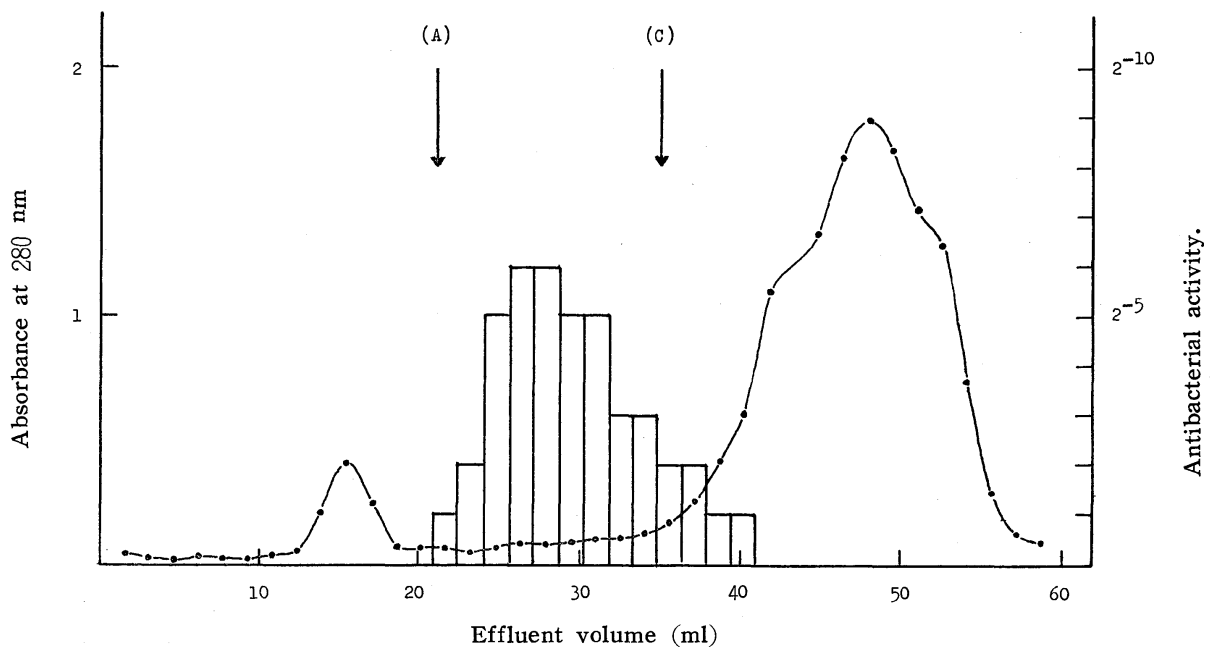

Fig. 1 Gel filtration of culture filtrate of Te-tep callus by Sephadex G-100 column. Arrows (A) and (C) indicate the positions of elution of albumin (serum) and cytochrome $\mathrm{C}$, respectively, which were used as markers. Antibacterial activity was expressed as degree of the maximal dilution, in which each fraction was able to form the inhibition zones around cups on the assay medium plate. 
the medium containing 2,4-D) was incubated for $24 \mathrm{hrs}$ at $27 \mathrm{C}$ and the mixture was then fractionated by Sephadex G-25 column. The antibacterial activity was found mostly in low molecular weight fractions. After the active fractions were collected and concentrated to a small volume, the concentrate was developed by paperchromatography using solvents of (a) isopropanol-water (5:95) and (b) isopropanol-water $(60: 40)$. Rf value of the active substance was found as 0.75 and 0.98 , respectively, which seemed to correspond with those of 3-hydroxymethyloxindole. However, the recovered activity was not stable, being decreased gradually during the process of further purification.

\section{Discussion}

Fukuyama et al. ${ }^{1)}$ reported that 3-hydroxymethyloxindole and 3-methyleneoxindole were found to be photodecomposed compounds from IAA and these substances were toxic for growth of Escherichia coli. This inhibition was transitory, since both compounds were converted to a non-toxic compound, 3-methyloxindole. 3-Methyleneoxindole was first identified by Hinman et $a l .{ }^{3)}$ as a product from IAA by horseradish peroxidase.

Using a preparation of an IAA oxidase from Parethenocisus tricuspidata, Hamilton et al. ${ }^{2)}$ found 3-hydroxymethyloxindole as an intermediate in the enzymatic reaction and non-enzymatic conversion of it to 3-methyleneoxindole. The in vivo study showed that although $53 \%$ decarboxylation of IAA was observed in $48 \mathrm{hrs}$, only a small amount of 3-methyloxindole could be recovered from the reaction medium.

Rubery9) obtained an IAA oxidase fraction from a tissue culture of crown gall of Parethenocisus tricuspidata and showed that this IAA oxidase required $\mathrm{Mn}^{++}$and a monohydric phenol for the IAA oxidation. Malic acid or other compounds of related structure also stimulated this enzyme activity.

In the present study, three facts has been shown. First, the antibacterial component secreted from rice callus tissues has high molecular weight of around 32,000. Secondly, IAA and $\mathrm{Mn}^{++}$are necessary for the antibacterial activity to be added to the assay medium. Thirdly, as the intermediate product in the incubation of combination of IAA, $\mathrm{Mn}^{++}$, and the culture filtrate, 3-hydroxymethyloxindole was detected. To add to these, the antibiotic activity was stimulated by addition of $p$-chlorophenol to the assay medium. These facts suggest that the component found in culture filtrate of rice callus is also one of the IAA oxidizing enzmes and the antibiotic activity against $X$. oryzae is due to intermediates produced in degradation process of IAA by this enzyme.

Biological significance of this factor in the plant is not established. As one function it probably plays a role of leveling down surplus IAA in the plant. It is also possible that the enzyme may defend a plant from infection by the pathogens. The latter effect may be especially important in such conditions as the infection of the pathogen stimulate the plant to convert tryptophane to IAA metabolically. ${ }^{10)}$

Appreciation is expressed to Dr. A. Ezuka and Dr. T. Uematsu of this Institute for kindly providing bacterial type cultures and rice seeds.

\section{Literature cited}

1. Fukuyama, T. T. and Moyd, H. S. (1964). J. Biol. Chem. 239 : 2392-2397

2. Hamilton, R. H., Meyer, H. E., Burke, R. E., Feung, C. S. and Mumma, R. O. (1976). Plant 
Physiol. 58 : 77-81

3. Hinman, R. L., Bauman, C. P. and Lang, J. (1961). Biochem, Biophys. Research Communs. $4: 250-255$

4. Horino, O. (1977). Ann. Phytopath. Soc. Japan $43: 347$

5. Horino, O. and Ezuka, A. (1972). Ibid. $38: 200$

6. Horino, O. and Sato, Z. (1976). Ibid. $42: 359$

7. Murashige, T. and Skoog, F. (1962). Physiol. Plantarum $15: 473-479$

8. Nakanishi, K. and Watanabe, M. (1977). Ann. Phytopath. Soc. Japan 43 : 265-269

9. Rubery, P. H. (1972). Biochem. Biophys. Acta $261: 21-34$

10. Sequeira, L. (1973). Ann. Rev. Plant Physiol. $24: 353-380$

11. Watanabe, M. (1963). Ann. Phytopath. Soc. Japan $28: 201-208$

和 文 摘 要

$$
\begin{gathered}
\text { インドール酢酸とイネ・カルス組織の培養濾液との組合わせによる } \\
\text { イネ白葉枯病菌の生育阻害 }
\end{gathered}
$$

\section{深見悌一}

イネ・カルス組織を 4 品種のイネの芽生えより誘導した。イネ白葉枯病菌を被験菌とし，インドール酢酸 を含んだ平板培地上で試験すると，乙れらのカルス組織はその培養時に，乙の細菌に対して抗菌性をむつ高 分子性の成分を培地中に分泌することが認められた。カルスの培養に用いた Murashige-Skoog 培地への各 種植物ホルモンの添加が，カルス組織の生育ととの抗菌性成分の分泌に対して如何に影響するかを，カルス を 3 週間 $27 \mathrm{C}$ で培養した後に調べた。品種金南風及び黄玉の カルス組織は植物ホルモン (IAA, $2,4-\mathrm{D}$, NAA あるいは kinetin) の低濃度 (0.05ppm あるいはそれ以下) を添加した時, 比較的少量の抗菌性成分 を分泌した。より高濃度 $(0.5 \mathrm{ppm} \sim 20 \mathrm{ppm})$ の $2,4-\mathrm{D}$ を加えた培地で培養した場合，金南風及び黄玉カル ス組織の培地中に見出される抗菌活性は増大し, Te-tep 及び早稻愛国 3 号の培地中に見出される抗菌活性之 同じ程度になった。一方，Te-tep あるいは早稲愛国 3 号種からの活性成分の分泌は低濃度 $(0.05 \mathrm{ppm}$ ある いはそれ以下）の植物ホルモンを加えた培地で生育した時でさえ屯比較的多く，大抵の場合金南風あるいは 黄玉からの分泌量の10倍から100倍に達した。

この抗菌成分は分子量約 32,000 の高分子性物質であるとと， $\mathrm{Mn}^{++}$を cofactor として要求するとと， monohydric phenol の添加によって活性が増大すること等の理由から IAA 酸化酵素の一種と推定された。 